\title{
Grille Device
}

National Cancer Institute

\section{Source}

National Cancer Institute. Grille Device. NCI Thesaurus. Code C49971.

A framework of bars designed as a covering or divider. 